International Research Journal of Management, IT \& Social Sciences
Available online at https://sloap.org/journals/index.php/irjmis/
Vol. 7 No. 6, November 2020, pages: 72-78
$\begin{aligned} & \text { ISSN: 2395-7492 } \\ & \text { https://doi.org/10.21744/irjmis.v7n6.1013 }\end{aligned}$

\title{
Strong State and Weak Minority in Post-Civil War Sri Lanka: A Study based on State-in-Society Approach
}

Article history:

Submitted: 27 August 2020

Revised: 09 September 2020

Accepted: 18 October 2020

\section{Keywords:}

civil-war;

consolidation;

minority;

society;

state;

\begin{abstract}
This study aims to analyze the strong state of Sri Lanka that emerged after the civil war during the regime of Mahinda Rajapaksa. The Liberation Tigers of Tamil Eelam (LTTE) was the leading Tamil militant social force, which was waging war against the government to form a separate state in the northern and eastern regions of Sri Lanka. The government ended both the separatist struggle of the LTTE and the civil war in May 2009 by winning a major military victory. This study is a qualitative analysis based on text analysis and field interviews, supplemented with limited observations. The study reveals that the state introduced enhanced security measures to avoid possible LTTE regrouping and re-commencement of violence in the country. The state also attempted to fragment minority parties to weaken the state reconstitution process through penetration and regulation of the social order.
\end{abstract}

International research journal of management, IT and social sciences (C) 2020. This is an open access article under the CC BY-NC-ND license (https://creativecommons.org/licenses/by-nc-nd/4.0/).

\section{Corresponding author:}

Mohamed Anifa Mohamed Fowsar,

Senior Lecturer, Department of Political Science,

Faculty of Arts and Culture, South Eastern University of Sri Lanka.

Email address: fowsarma@seu.ac.lk

\footnotetext{
Department of Political Science, Faculty of Arts and Culture, South Eastern University of Sri Lanka Department of Political Science, South Eastern University of Sri Lanka
} 


\section{Introduction}

The highly centralized unitary model of the Sri Lankan state structure was inherited from the British colonial master's reproduction of the Westminster model of parliamentary government which was centralized both politically and administratively. The multiple ethnic nature of Sri Lankan society and the unitary feature of the state have been fundamental grounds for state and society contestation in the post-colonial era. There is an argument that focuses on a paradox in which the state introduces policies in favor of the majority Sinhalese masses and undermines policies in the direction of another domain of the Tamil minority. The Sinhalese political elites had established a special relationship and favor for their people to earn support in the election which promoted Sinhala nationalism and the state's domination towards Tamils. This state alliance with Sinhalese society provided the opportunity for the formation of a majoritarian 'strong state' in the post-colonial period.

The Tamil community's experience of discrimination and political exclusion had produced a particular project of minority aspiration that transformed into a demand for federalist regional autonomy. Sinhalese political elites had repeatedly and consistently failed to see the growing crisis of the state despite demands made by the Tamil minority social forces to reconstitute the post-colonial Sri Lankan state. Politics of the majority such as the centralization of unitary state power and counter politics of the minority such as the promotion of secession, both mutually transformed state, and social relations. The immediate circumstances that saw the transition of Tamil ethnic politics from a demand for regional autonomy to secession evolved in the late 1970s. Tamil youths rose and formed several armed groups in the line of Tamil nationalist ideology, to establish a separate state called Tamil Eelam (Carment et al., 2006; Balasingham, 2004; Wilson, 2000).

The LTTE was one of the many militant organizations that took up arms against the Sri Lankan state. The LTTE was a strong social force that had been able to capture and control substantial parts of the Sri Lankan territory. The LTTE acted like the sole representative of the Tamil minority, and most of the people also accepted them. The LTTE's alliance with local Tamil people and wings of Diaspora led to the attempt for reconstitution of state during the war period. To understand puzzling issues, the existence of the LTTE in the last three decades brought it as a social force of Tamils and a voice of theirs which shaped and formed a strong Tamil society. The civil war between the LTTE and government forces came to a bitter end in May 2009, after nearly three decades, when the LTTE was comprehensively defeated by the Sri Lankan government (Hoglund \& Orjuela, 2011). With the defeat of the LTTE, the entire island came under state control which transformed the state into a strong unitary state once again, and Tamil Society weakened. The end of the war evolved with a strong state and a weak Tamil society. It is a very difficult juncture in which to reconstitute a strong state via the contestation of weak post-LTTE Tamils.

\section{Materials and Methods}

The state-in-society approach described by Joel S. Migdal was applied to this study to discuss the contestations between the state and its minority community in post-war Lanka. According to Migdal (2013), the state-in-society approach is significant because it inspires us to examine not only those everyday social forces that challenge, shape, and reconstitute the authority of the state, but also the deep-seated ideational norms that simultaneously perpetuate the authority of the state over enormous geographic spaces (a far less systematically explored dynamic). The instruction to decenter state authority while simultaneously retaining the normative idea of the state as a core unit of analysis distinguishes. Migdal's state-in-society approach from those of his contemporaries in the field of everyday politics. The approach presented by Migdal offered insight within the political discipline. He also led to a slew of researchers directly inspired by his work and the blueprint to conduct a novel study on the relationship and dynamics between the state authority and our everyday life (Fazil, 2019a).

This is a qualitative study based on text analysis and field interviews, supplemented through the observations subjected to limitations. In this section, the author discusses the methodology and its relevance to Sri Lanka. The main stakeholders of the state-minority contestations in Sri Lanka were considered as the key categories in this study, specifically, the state and society (minority). These key categories can be further divided into several sub-categories. Qualitative data are collected and analyzed and used as bases for these key categories. These categories with a wide range of interests in mind were selected to gather maximum variations in responses to obtain views from diverse perspectives.

Fowsar, \& Fazil. (2020). Strong state and weak minority in post-civil war Sri Lanka: A study based on state-insociety approach. International Research Journal of Management, IT and Social Sciences, 7(6), 72-78. 
The two selected key categories were two national actors to cover the state and minority stakeholders of the contestations. The local or national key categories are all living in Sri Lanka, but they manifest different political positions, hierarchical structures, ethnicity, religion, and culture. The author employed purposeful sampling when selecting the respondents. The data used in this research corresponds to an extensive literature survey to collect all relevant data on post-independent state formation and state-minority contestations that occurred in the country, 20 indepth qualitative interviews (conducted during November 2015-April 2016 and an additional interview in April 2017), supplemented with a process of limited field observations and reflections. The two-step approach was followed for the qualitative data collected during the period 2013 to 2017.

The critical and interpretative approaches were used for data analysis, and the study combined the empirical methods, classified, and weighed from sources such as interviews, observations, and field notes. The extract transcribed data were processed for consistency and coherency in a descriptive theme to help the study to conclude. Thus, this paper reviews the reasons why the state has not responded with inclusive policies to prevent another major conflict. It examines the image presented by and the actual practices of the state of Sri Lanka to avoid inclusive policies designed to accommodate the Tamil minority into the state system, after the end of the civil war and defeat of the secessionist militant social force (Fearon \& Laitin, 2011; Sharma, 2006).

\section{Results and Discussions}

Migdal (1988), argues that "for a state to survive and be able to gain strength, it has to have the ability to mobilize the society and have the capability to penetrate society, regulate social relationships, extract resources, and use resources appropriately. Strong states are those with high capabilities to complete these tasks, while weak states find it difficult." Migdal (1988), also points out that there should be skillful leadership as an important condition for creating a strong state. In the case of Sri Lanka, Rajapaksa was a skillful leader to form a strong post-war state. His credibility and mass appeal as a political leader raised because of ending the civil war against the LTTE. He was also successful in proving his capability to mobilize the people to vouch for him that helped him to emerge victorious in the presidential and parliamentary elections held in 2010 (De Votta, 2010). These two electoral contests; the presidential election on January 26, 2010, and parliamentary election on April 8, produced huge social mobilization and the people provided extended support to Rajapaksa and his United People's Freedom Alliance (UPFA) coalition. Incidentally, the UPFA consisted of political and ideological forces that had in the past stood for the oppressive perspectives of unitarism and devolution in the state reconstitution of Sri Lanka.

The war led the unitarist state to reform its perspective to gain an ideological and political upper hand within the UPFA regime. The parties in support of President Rajapaksa's bid for a second term included hard-line parties such as the JHU, Mahajana Eksath Peramuna (MEP - People's United Front), and last but not least the National Freedom Front (NFF), the party that denied the existence of ethnic conflict in Sri Lanka and also opposed the system of provincial councils. The need for power-sharing arrangements with ethnic minorities at the regional level was refuted by these parties, and they were in support of a strong executive presidency on the argument that it was a safeguard against future attempts at secession (Marcelline \& Uyangoda, 2013). President Rajapaksa at the end of the civil war forwarded his quest to rebuild a fresh path for the state in line with unitary rule favoring his strongman style of politics (Wickramasinghe, 2009; Vineyard, 1957; Wootters \& Fields, 1989; Allahyari et al., 2018).

For creating a strong state, the emergence and growth of such radical social forces within the Sinhalese majoritarian politics were important. To make his regime stronger, he also had the support of the pro-devolution left parties as well as the ethnic minority parties. This included the Eelam People's Democratic Party (EPDP), the Tamil Makkal Vidutalaipulikal (TMVP), All Ceylon Muslim Congress (ACMC), and the Ceylon Workers' Congress (CWC). All of them continued to argue the need for a sustainable political solution to the ethnic conflict (Marcelline \& Uyangoda, 2013). These minority social forces were not by any means a replacement for the defeated LTTE and hence were unable to contest with the state. This enabled the formation and continuation of a strong state by Rajapaksa. Consequently, the lack of political balance of forces within the UPFA regime disrupted the opportunity for state transformation and reconstitution. A strong state should have the capability to penetrate society and regulate social relationships (Migdal, 1988).

The strong state used the post-war situation to its favor to maximize its ability to penetrate the Tamils who were in disarray and aimed to deregulate their social relationships in the northern and eastern provinces. As a result of the long drawn out war, Tamil society was an extremely affected and vulnerable community. They had lost loved ones, property, and livelihood got displaced, and became refugees (Fazil, 2019b). The state increased its capacity and set up certain 
tools to penetrate society and regulate social relations. First, the organization and mobilization of Sri Lanka Security forces (SLSF). Upon becoming President Rajapaksa took office as the Defence Minister and assigned secretary of the Defence Ministry to his brother Gotabhaya, a former officer in the military, and this led to a remarkably close connection between the civilian and military commands (De Votta, 2009a).

General Sarath Fonseka played a major role to defeat the LTTE in the Rajapaksa regime. In the post-war situation, General Fonseka claimed not to have supported Gotabhaya in utilizing the army for the malpractices and extrajudicial purposes. Gradually, Fonseka was side-lined, removed from the post of the army chief, and alienated in the military activities of the state. General Fonseka went on to join the opposition and contested the January 2010 presidential election which he lost. With his election loss, Sarath Fonseka was politically victimized by the Rajapaksa regime. He was due to be charged rather cunningly, in both military and civilian courts.

The state's main concern was the threat of post-LTTE Tamils' regrouping and restarting the conflict. For that reason, "both the Criminal Investigation Department (CID) and Terrorism Investigation Department (TID) were strengthened, and also paramilitary group members (TMVP, EPDP, Karuna faction, etc.) and ex-combatants amalgamated with CID and TID. Members of CID, TID, and their support wing were assigned to stay together with people in the former LTTE-controlled villages or areas. They penetrated society to monitor ex-combatants and worked as a shadow to regulate their social relationships. They occasionally visited and investigated ex-combatants to monitor their relationship with youths, International Non-Governmental Organizations (INGOs), foreigners, media personals, and researchers" (personal communication, March 17, 2016). "The state had suspicions that ex-combatants could betray the military secret of war crime activities during the final battle and about the shortage of post-war peacebuilding activities which could easily reach the international human rights organizations and media" (personal communication, December 12, 2015). State security divisions not only monitored the ex-combatants but were also suspicious of civilians such as youths, government servants, Non-Governmental Organisations (NGO) representatives, media personnel, and local politicians. These regulatory activities denied a return to normalcy in the former war-torn areas (personal communication, March 16, 2016)

"The state tightened security by establishing new navy camps and army camps in focal points to avoid arm trafficking and police stations to maintain civil administration. Civilians in these areas felt insecure due to the presence of security forces and complained and submitted requests to the state directly as well as via area politicians; however, there were no noticeable changes taking place" (personal communication, March 21, 2016).

In the meantime, "the state introduced other security strategies within the North, East and other parts of the country by dividing SLSF into separate teams along with other paramilitary groups whose roles entailed abduction, assault, robbery, extortion, imprisonment, murder, and disappearances, though the notorious white vans. White van targets included media personnel, businessmen, ex-combatants, politicians, social workers, NGO representatives, and any other persona non-grata of the regime" (personal communication, February 13, 2017).

The state, meanwhile, introduced a lot more measures where they focused primarily on the north and eastern areas. Their primary aim was to ensure; the paramilitary is not only tasked with securing the war-torn regions for the state but also to morphing them into so much into "grease devils". This phenomenon was coined to instill fear where they were described as naked or semi-naked men smeared in grease allegedly assaulting women across the north and eastern areas. Attacks were frequently recorded, leading to demonstrations and local population reprising (Goodhand, 2012).

The state's constant attempt to weaken the state's reconstitution ideology was construed by working towards fragmenting the affected populace through various policies. By penetrating the society to overtake them, to regulate them eventually, the state intended to control the region under their political and social grip. During the war, local Tamil politicians and parties such as All Ceylon Tamil Congress (ACTC), Eelam People's Revolutionary Liberation Front (EPRLF) (Suresh Wing), Tamil Eelam Liberation Organization (TELO), and Tamil United Liberation Front (TULF) formed a coalition. They made them the sole political representative of the Tamil people. This coalition, commonly known as TNA continues in that role into the present day. It rewarded them with substantial seats in the parliamentary elections (Mayilvaganan, 2008).

In the aftermath of the parliamentary election of January 2010, the TNA won 14 seats, the highest number of seats for a single party from the North and East, and also began to move towards a more reconciliatory position with the UPFA government. Significantly, at the parliamentary elections of 2010, the TNA dropped from the electoral list to those candidates who were seen to be pro-LTTE and instead chose candidates who held seemingly moderate views. In its more conciliatory approach, the TNA emphasized that there was a trust deficit between itself and the government and wanted to address it. Central to the TNA argument was the point that a move away from antagonistic politics would facilitate their inclusion in the reconstruction and development process in the North and East, and in a political process towards power-sharing. This change of approach of the TNA appeared to be based on the understanding that

Fowsar, \& Fazil. (2020). Strong state and weak minority in post-civil war Sri Lanka: A study based on state-insociety approach. International Research Journal of Management, IT and Social Sciences, 7(6), 72-78.

https://doi.org/10.21744/irjmis.v7n6.1013 
the end of the civil war, and the end of the LTTE, had transformed the political framework for a debate on state reconstitution requiring new strategies for dealing with the Sinhala political elite (Marcelline \& Uyangoda, 2013). During the civil war, the LTTE in its quest for alternative sovereignty had framed the minority rights discourse within the conceptual framework of external self-determination.

The TNA tried to re-design the Tamil political plan within the framework of devolution of power, in the new postcivil war political context in which the LTTE no longer shaped the minority rights discourse. There was a shift in policy from a pre-civil war period to a post-civil war one. In the pre-civil war period, the ethnic Tamil project for equal recognition and power-sharing was based on a demand for internal self-determination in the form of a federal arrangement. Whereas in the post-civil war context, the Tamil project seems to have a more significant commitment to reforming the Sri Lankan state than to secession. This shift is seen in the consensus among all Tamil parties to advance their politics of group rights through a federal arrangement or a system of enhanced powers to the provincial council. The Indian constitutional arrangement of power-sharing and policies of affirmative justice, or positive discrimination for disadvantaged communities, are cited as examples to draw (Marcelline \& Uyangoda, 2013).

On the one hand, the ruling class attempted to weaken TNA, Tamil mainstream political part, and aligned with anti-LTTE parties of EPDP and TMVP in Tamil politics. The Sri Lankan state was now in a position to use these antiLTTE Tamil satraps to show intra-Tamil divisions (De Votta, 2009b) to the international community and use them to strengthen state survival and for the dilution of the TNA's demand for post-war state reconstitution. To further strengthen a strong unitary state and consolidate power, the ruling UPFA accepted other minority parties such as CWC to join as a coalition. Finally, the Sri Lanka Muslim Congress (SLMC) crossed over from opposition leading to the 2/3rd majority it needed to pass the amendment, backing the 18th Amendment (Marcelline \& Uyangoda, 2013).

Thirdly, radical outfits and hate campaigns were getting promoted within the ruling coalition. It was a prominent voice of dissent the NFF, a breakaway faction of the Jantha Vimukthi Peramuna (JVP), and its leader Wimal Weerawansa. This faction was encouraging further centralization of state power on the basis that federalism was the only demand of Tamil politicians and not that of the common Tamil people (Daily Mirror, 2009).

Another constituent member of the government, the Jathika Hela Urumaya (JHU - Sinhalese National Heritage Party), held a similar view. Despite being junior partners of the UPFA coalition with only three MPs between them, both these radical parties were ideologically influential in shaping the UPFA's policies on the ethnic conflict and war. The JVP on the other hand, while promoting the argument for post-conflict economic development and reconciliation, called on the government to block all attempts to devolve power based on the 13th Amendment (Daily Mirror, 2009, June 1, pp. $1 \& 6$, as cited in Marcelline \& Uyangoda, 2013). In the meantime, researchers and observers attest to the mechanization of the state behind the radical elements in the country during the last phase of the previous regime. The Bodu Bala Sena (BBS) and Sinhala Ravaya were encouraged to promote hate campaigns against the minority and state reconstitution project to find a resolution to the ethnic conflict.

Thus, the state and its potential leader implemented these survival strategies to penetrate society and regulate social relationships for the continuation of a strong unitary state and soft authoritarianism in post-war Sri Lanka, making the state reconstitution demand of the minorities meaningless.

Migdal (1988 \& 2001), suggests another strategy of the strong state is to extract resources and use those resources appropriately. This theory of Migdal's state-in-society approach can be applied to the post-war strong state's recovery, reconstruction, and development activities under the peace-building process. During the civil war, the land was demarcated under the Cease Fire Agreement (CFA). The Sri Lankan state-controlled their area while the LTTEcontrolled its area. Accordingly, with the defeat of the LTTE, the state recaptured land, sea, and other resources and dominated entire areas of the island on its path to strengthen the strong state of Sri Lanka. Jayawardena (2009) demonstrates how the state developed misconceptions among the majority Sinhalese and mobilized them against minorities' demand for the reconstitution of the unitary state (self-determination):

An article published in the Sunday Times FT on September 25, 2009, under the title 'ISGA Eyes Lion's Share' "effectively pointed out that the LTTE was trying to take control of a major portion of Sri Lanka's marine, maritime offshore, and natural resources. It is a great blessing that the ISGA (Interim Self Governing Authority) was not implemented by the then government and if so the rest of the country would have been subservient to an independent state of Tamil Eelam. Now that the LTTE menace is over, we must look at the development of natural resources in the eight districts - Amparai, Batticaloa, Jaffna, Kilinochchi, Mannar, Mullaitivu, Trincomalee, and Vavuniya. These districts are about $18,323 \mathrm{sq} . \mathrm{km}$ or about $30 \%$ of the total land area of $65000 \mathrm{sq} \mathrm{km}$ of Sri Lanka. The population of these districts according to the last census carried out in 1995 is 2.6 million which is about $10 \%$ of the total population of Sri Lanka estimated at $19-20$ million. Therefore those who advocate traditional homelands for one community 
should realize that $10 \%$ of the population in the country occupies nearly $30 \%$ of the land area and the rest of the 90 $\%$ occupy the balance $70 \%$, and no one can dispute this highly inequitable distribution."

The state incorporated all the resources from north and east into the national Gross Domestic Product (GDP). It gained revenue which during the LTTE period did not fully contribute to the national economy. These include paddy cultivation, vegetables, and fruits, including grapes, seafood, forestry, water resources, etc., and mineral resources with the major resource being the heavy mineral sands at Pulmoddai. Sea resources include deep-sea fishing and Miocene limestone, where there are large cavities etc. (Jayawardena, 2009).

"The LTTE maintained financial administration in their controlled areas and established the Tamil Eelam Bank with several branches. Civilians deposited a lot of money and pawned jewelry at the so-called banks during the civil war. At the end of the war, SLSF captured huge amounts of money and valuable kilos of jewelry in the north" (personal communication, December 3, 2015). These activities of the state can be described as the extraction of resources from the LTTE and Tamil people. It can be argued here that the extracted money and jewelry belongs to the Tamil people. It was expected that the state would return these belongings of innocent people in the aftermath of the war. However, in reality, only some people were identified by the army and had their jewelry distributed to them after five years since the termination of the war. Some 1,960 identified owners from Mannar, Vavuniya, Mullaithivu, and Kilinochchi received their belongings, according to presidential officials (Firstpost, 2014). There is a crucial question placed before the state as to 'what happened to the balance jewelry?' Is it difficult to find sources about the accountability of people's money and what happened to it?.

\section{Conclusion}

This paper aims to project attention towards the fact that the end of the war created a golden opportunity to reconstitute the state away from a unitary model to a more open and flexible state system. The state could have been adopted a more inclusive policy in the post-war era. However, the will to implement the reconstitution of the state was thwarted and abandoned at the most opportune moment. President Rajapaksa, who formed a strong post-war government, has exploited his popularity as a leader who defeated the LTTE, for his political mileage. The masses swayed by his proposition; the people thronged as a flock to vote for him, cementing his fame among the political and Sinhalese majority elites. His government, according to Migdal's theory, merged the position of the state as a rigorous structure that worked rapidly to weaken the minorities. Through the imposition of various political and social regulations favoring the majoritarian state, it nullified the minorities' concerns in the post-war context. There were various strategies deployed to penetrate the society, regulate socially established structures, and dismantle minority political parties by fragmenting them. In line with this approach, the TNA who were the keen proponents of the federal system were positively nudged to accept the coalition by a few concessions that didn't affect the majority. It led the TNA to concede by making them drop pro-LTTE sentiments in their party. The government carefully crafted alignment with anti-LTTE Tamil parties such as Eelam People's Democratic Party (EPDP) and Tamil Makkal Viduthalai Puligal (TMVP). Through these crafted approaches, the state merged with the establishment of centralized economic development. The state machinery was stoking the sentiments of the majority through radical anti-minority parties and propagating hate campaigns. They covertly promoted their agenda. It deemed the extraction of resources from the northern and eastern areas and redistribution acceptable by the government and followed it as a state policy.

\section{Conflict of interest statement}

The authors declared that they have no competing interests.

Statement of authorship

The authors have a responsibility for the conception and design of the study. The authors have approved the final article.

\section{Acknowledgments}

We are grateful to two anonymous reviewers for their valuable comments on the earlier version of this paper.

Fowsar, \& Fazil. (2020). Strong state and weak minority in post-civil war Sri Lanka: A study based on state-insociety approach. International Research Journal of Management, IT and Social Sciences, 7(6), 72-78. 


\section{References}

Allahyari, M. S., Damalas, C. A., Masouleh, Z. D., \& Ghorbani, M. (2018). RETRACTED: Land consolidation success in paddy fields of northern Iran: An assessment based on farmers' satisfaction. https://doi.org/10.1016/j.landusepol.2018.01.035

Balasingham, A. (2004). War and peace. Armed Struggle and Peace Efforts of Liberation Tigers. Mitcham: Fairmax Publishing.

Carment, D., James, P., \& Taydas, Z. (2006). Who intervenes?: ethnic conflict and interstate crisis. Ohio State University Press.

Daily Mirror. (2009). JVP submits post-conflict plan to president.

Daily Mirror. (2009). Political power should be centralised says Wimal.

Devotta, N. (2009). Sri Lanka at sixty: A legacy of ethnocentrism and degeneration. Economic and political weekly, 46-53.

DeVotta, N. (2009). The liberation tigers of Tamil Eelam and the lost quest for separatism in Sri Lanka. Asian Survey, 49(6), 1021-1051.

DeVotta, N. (2010). From civil war to soft authoritarianism: Sri Lanka in comparative perspective. Global Change, Peace \& Security, 22(3), 331-343.

Fazil, M. M. (2019). Migdal's theory of the state-in-society in the context of Sri Lanka: a critical review.

Fazil, M. M. (2019). State-minority contestations in post-colonial Sri Lanka. Journal of Educational and Social Research, 9(4), 157.

Fearon, J. D., \& Laitin, D. D. (2011). Sons of the soil, migrants, and civil war. World Development, 39(2), $199-211$. https://doi.org/10.1016/j.worlddev.2009.11.031

Firstpost. (2014). Sri Lanka: President Rajapaksa returns gold, jewellery taken by LTTE to people.

Goodhand, J. (2012). Sri Lanka in 2011: Consolidation and militarization of the post-war regime. Asian Survey, 52(1), 130-137.

Höglund, K., \& Orjuela, C. (2011). Winning the peace: conflict prevention after a victor's peace in Sri Lanka. Contemporary Social Science, 6(1), 19-37.

Jayawardena, D. (2009). Assessment and development of natural resources in North-East. Financial Times of the Sunday Times.

Marcellin, S., \& Uyangoda, J. (2013). Post Civil War Sri Lanka: The Dilemmas of State Reform. State Reform in Sri Lanka: Issues, Directions and Perspectives, Colombo: Social Scientists 'Association.

Mayilvaganan, M. (2008). Is it Endgame for LTTE?. Strategic Analysis, 33(1), 25-39.

Migdal, J. S. (1988). Strong societies and weak states: state-society relations and state capabilities in the Third World. Princeton University Press.

Migdal, J. S. (2001). State in society: Studying how states and societies transform and constitute one another. Cambridge University Press.

Migdal, J. S. (2013). The everyday life of the state: A state-in-society approach. University of Washington Press.

Sharma, K. (2006). The political economy of civil war in Nepal. World Development, 34(7), 1237-1253. https://doi.org/10.1016/j.worlddev.2005.12.001

Vineyard, G. H. (1957). Frequency factors and isotope effects in solid state rate processes. Journal of Physics and Chemistry of Solids, 3(1-2), 121-127. https://doi.org/10.1016/0022-3697(57)90059-8

Wickramasinghe, N. (2009). After the war: a new patriotism in Sri Lanka?. The Journal of Asian Studies, 68(4), 10451054.

Wilson, A. J. (2000). Sri Lankan Tamil nationalism: Its origins and development in the nineteenth and twentieth centuries. UBC Press.

Wootters, W. K., \& Fields, B. D. (1989). Optimal state-determination by mutually unbiased measurements. Annals of Physics, 191(2), 363-381. https://doi.org/10.1016/0003-4916(89)90322-9 